\title{
Problematization of Social-and-ecological Aspects in Adaptation of the Forced Migrants in Stavropol Krai
}

\author{
Tatiana Nikolaevna Dukhina ${ }^{1}$, Svetlana Ivanovna Tarasova ${ }^{1}$, Evgeniya Vladimirovna Taranova ${ }^{1}$, Elena \\ Borisovna Zorina $^{1} \&$ Olga Alekseevna Chudnova ${ }^{1}$ \\ ${ }^{1}$ Stavropol State Agrarian University, Russian Federation \\ Correspondence: Tatiana Nikolaevna Dukhina, Zootekhnichesky lane, 12, Stavropol, 355000, Russian \\ Federation.
}

Received: November 19, 2014

Accepted: December 9, 2014 Online Published: March 20, 2015

doi:10.5539/ass.v11n8p127

URL: http://dx.doi.org/10.5539/ass.v11n8p127

\begin{abstract}
The article represents the scientific-theoretical analysis of the socio-ecological aspects in adaptation of the forced migrants in Stavropol Krai. The features of ecological and physiological adaptation of migrants taking into account ecologic-physiological, medical-demographic, socio - legal characteristics in particular community development are shown in it. It is denoted the indicators which influence on the migrant flows. Among such indicators there are dynamics of diseases among population, problem of quality and quantity of food, employment, working conditions, common conditions of environment.
\end{abstract}

Keywords: social ecology, socio-ecological environment of person, ecological migrants, socio-ecological indicators of migration

\section{Introduction}

A great number of people appears as the forced migrants due to the international conflicts, numerous natural disasters and cataclysms, in many situations - hunger and poverty.

Last decade in scientific community of socio-ecologists more attention is paid to studying questions of the increasing ecologic and social crisis which consequences strengthen the forced migration of population. The scientists see the reasons of this crisis in a number of factors, among which: deterioration of work and life conditions, quality and quantity of food, level decrease of ecological culture among population, stressor, etc. (Gabdrakhmanova, 2003; Dukhina 2014).

These factors making socio-ecological environment of person, undoubtedly, have impact on such indicators as: level of mental and physical health of population, longevity, birth rate, mortality, social and economic behavior and migration (Information and Analysis bulletin, 2013; Soldatova, 2001).

Therefore an important problem is studying complex action of social and natural factors of environment on process of person adaptation in community. This problem has special actuality in a context of adaptation features research of the forced migrants for whom adaptation process is most difficult in the conditions of receiving community, and it is necessary to consider cumulative influence of a number of environmental factors - social, geographical, demographic, ecological, economic, cultural, political, etc. (Efimov, 2006; Ryabtsev, 2006; Olejnikov, 2001; Galich, 2006).

Last decade the concept "ecological migrants" which recognized "as the persons suddenly or unexpectedly forced to run from their houses in a great number because of natural or human-induced disasters" was widely adopted (Gudwin-Gill, 1997). Ecological migration can be caused by natural disasters and accidents, and also technogenic processes.

The authors support V. I. Evtushenko's point of view who distinguishes migration because of ecological and technogenic catastrophes and migrants leaving places of the usual residence because of gradual deterioration of ecological, sanitary and epidemiologic situation, change of climatic conditions, environment, etc. (Evtushenko, 2010). 


\section{Method}

In view of that the migrant adaptation problem is one of the parts of demographic problem. We will consider it taking into account ecological and physiological, medico-demographic and social and legal features of concrete community development.

Ecologo-physiological features include examination of the living environment quality, function dependence from the human conditions of their life and work in different physiographic zones during different periods of a year, days; determine the physiological basis of adaptation to natural conditions.

Medico-demographic features include examination of food quality, sanitary and hygienic conditions of work and life, rate of birth and mortality, psychological and emotional state of environment, genetic factors, distribution of socially significant diseases, etc.

Socio-legal features focus on studying opportunities in doing by the man regulatory requirements and legal norms of the receiving community, and the state of the normative framework that protects rights and interests of individuals in the community, and defining their social and legal status (Gritsenko, 2006).

In science there are a lot of definitions for personal adaptation and its types. The author does not attempt to give a thorough analysis of these definitions, but in relation to the identified problem of the research the concept of (ecological and physiological adaptation) will be used.

The authors refer ecological-physiological adaptation of migrants to the process of their adaptation to the peculiarities of socio-ecological environment in receiving communities, involving the activation of both functional and structural systems of the human organism, as well as his physical abilities and capacities in the conditions of receiving natural-climatic environment.

Great interest in research of ecological-physiological adaptation of migrants from concrete region represents an analysis of socio-ecological indicators of migration flows. Among such indicators there are dynamics of diseases among population, problem of quality and quantity of food, employment, working conditions, common conditions of environment (Gapich, 2006; Kobozeva, 2006).

According to analytical data in Russian regions Stavropol Region shows the highest dynamics of migration processes.

As follows from the information of the Department of the Federal migration service in Stavropol Region, for 6 months of 2013163908 citizens were registered in our territory.

Migration growth of population on Stavropolye over the past six months amounted to 537 people.

The largest number (112360) is the citizens of the Russian Federation, who arrived in the region for temporary stay.

Also 38699 people are foreign citizens arriving to the territory of Stavropol Krai in the visa and visa-free basis. Foreign citizens registered in stay place, came to the region with special aim $-60.6 \%$, business aim $-10.4 \%$, for work $-23.9 \%$, for tourism - $3 \%$, for education $-1.9 \%$.

The most prevalent (over 60\%) reasons for changing residence of migrants remain personal, family circumstances. Other reasons for displacement are work, study and return to the previous place of residence. From the total number of arrivals and departures, more than a half had no relatives at the new place of stay.

As "Stavropolstat" noted, in the migration exchange the persons with secondary and secondary special education are dominated - about $45 \%$ and about $87 \%$ of them are at the working age. In the region there is outflow of migrants with higher education, the reason for their relocation in almost $90 \%$ of cases is related with the work.

Migrants aged 14 years and older - almost a half - are married; never been married - almost 30\%; divorced and widowed - $15 \%$.

Main flow (96\%) of migrants aged 14 years and older are citizens of the Russian Federation, foreign citizens make up to $3 \%$, stateless persons less than $1 \%$ (The analytical report of the Ministry of Natural Resources and Environmental Protection of Stavropol Krai, 2008).

As it is seen, socio-cultural "portrait" of migration on Stavropol Territory is rather stable. Stavropol Krai since the beginning of the 90th in the XX century became real "shelter" for the forced migrants from the closest republics of the North Caucasus. According to this it should be noted its steadily stressful character caused by movement of people owing to war operations and mass riots in the North Caucasus, ethnic contradictions, and fight for distribution power. 
Now in Stavropol Krai the major factor leading to mass migration of people with higher and secondary special education is job search and additional earnings.

We will try to determine interrelation between two factors of migration in Stavropol Krai - social and natural (more precisely - ecological).

In a context of the certain region which Stavropol Krai is, difficulties in examination of socio-ecological indicators are connected, first of all, with absence of the uniform documentary base (reporting) giving complete performance of socio-ecological environmental condition in the region.

As a result of the analysis in some official documents the following conclusions about conditions of socio-ecological environment in Stavropol Krai (The State report of Department of "Rospotrebnadzor" in Stavropol Krai, 2012).

\section{Results}

\subsection{Ecologo-physiological Features of Migrant Adaptation}

According to N. R. Deryapa's opinion, the assessment of geographical environment and its influence on human body is one of the important problems of the person adaptation (Deryapa \& Ryabinin, 1977).

The ecologo-physiological factor of migrant adaptation to Stavropol Territory is presented by the general assessment of environmental and climatic conditions in this region, namely: impurity of atmosphere, safety of soils, water supply, level of radiation exposure, etc.

Migration connected with deterioration of environmental state in Stavropol Krai has the features.

On the one hand, Stavropol Krai still keeps the high productive potential of agricultural products, and according to some official data, it is one of the Russian leaders on wheat cultivation and export. As the agrarian region Stavropol Territory always was considered as a favourable place for accommodation, including moderate continental climate. The region possesses high potential of geothermal waters and mineral medicinal waters. The rivers and waste channels of the region have considerable energy potential. Situation of Stavropol Krai mainly in steppe and semi-desert zones creates good conditions for cultivation grain, vegetable, forage and other crops.

Stavropol Territory as a favorable place from the ecological point of view for accommodation is still considered by the migrants coming to Stavropol Territory, and the migrants leaving it. So, according to the poll of migrants by the Migratory Research Center in 2002 it is determined that the least popular reasons of moving population from Stavropol Krai to other regions of the country are "discrepancy of climatic conditions" and "ecological problems".

At the same time, according to the analytical report of the Ministry of Natural Resources and Environmental Protection of Stavropol Krai during the inspections carried out in the region on the state environmental control from 01.10.2011 it is observed that 899 offenses, from them 100-in the field of atmospheric air protection, 197in the field of using waste, 18- in the field of use and protection of water objects, 283- in the field of payment for negative impact on environment, 301- other violations.

In 2007 city Stavropol is included in the priority list of the cities with the greatest level of air pollution. In 2011 it is released into the atmosphere from stationary sources 67,9 thousand tons of polluting substances that is $3,3 \%$ more than in previous year. Gaseous and liquid substances from the enterprises in mining, production and distribution electric power, gas and water are thrown out practically without cleaning.

The radiation situation in the region is satisfactory for several years. Radiation accidents were not registered. Despite favorable radiation conditions in the region, there are a number of problems, which influence the dose formation of population: separate local areas of technogenic pollution in KMV region and oil-producing regions are registered, and rehabilitation of the territories with the former mining of uranium ore remains actual (The Federal Law from January 9, 1996).

Thus, on the one hand, social tension that accompanies the migration process on the Stavropol territory, to less extent due to natural problems and ecological situation in the region (despite of the obvious environmental causes for migration); on the other hand, it is noted that socio-economic causes become more often due to the need of increasing standard of living and active search for suitable employment.

\subsection{Medicos-demographic Peculiarities of Migrant Adaptation}

One of the indicators in the ecological-physiological migrant adaptation to the natural environment is the morbidity of the population living on the receiving territory. 
According to the State report of "Rospotrebnadzor" Department in Stavropol Krai (About the state of sanitary and epidemiological welfare of population in the Russian Federation in Stavropol Krai for 2012) analysis of morbidity on Stavropol territory for the period of 2007-2011 has shown that in this region remains high level of prevalence and primary morbidity in all age groups and for most classes of diseases.

In environmental impact assessment on health of population, the priority is the analysis of child morbidity, which is determined more territorial stability of children compared to adult working population, and increased sensitivity of the child's body. Children are less than adults exposed to intra-urban migration.

In the structure of newly diagnosed diseases of adults, children and teen-ages, as in previous years, the most prevalent are respiratory organs diseases $-31.3 \%$. The birth rate in 2011 is by $1.6 \%$ lower than in 2009 . For the last five years there has been a decrease in overall mortality by $13 \%$ from $14.2 \%$ in 2007 to $7.7 \%$ in 2011 , however, the number of deaths as a whole for $4.2 \%$ exceeded the number of births (Psychologists on migrants and migration in Russia, 2001).

Infant mortality is an important marker of sanitary-hygienic situation in the territory, more quickly than total mortality reacting to any changes in living and environmental conditions. In 2011 in the region 281 children under the age of 1 year died (in 2010 - 275). The infant mortality rate compared with 2010 increased by 3.6\%.

In regard to the quality of nutrition in Krai it is determined that in the last 5 years the specific weight of food samples not complying with hygienic standards on microbiological indicators have stabilized at the level of $2.7 \%$, according to sanitary-chemical indicators decreased from $1.2 \%$ to $0.3 \%$. In the $2010-2012$ food raw materials and food products containing genetically modified organisms (GMOs), are not identified (The Federal Law from February 19, 1993).

It should be noted that the epidemiological situation in the territory for the past five years was generally stable, ongoing prevention and control measures have also prevented the formation of mass epidemic focus in children's organized collectives, including the summer health improvement campaign.

However, the continuing external and internal migration and presence among migrants certain share of unimmunized people creates the risk of skidding infections, and a negative factor affecting the General epidemiological welfare of population.

According to the same report, in Stavropol Region there is a growth of mental disorders and socially significant diseases (first of all, alcohol dependence). Social ill health resulted in a high performance of anomalies and antisocial behavior - alcoholism and drug abuse, especially among young people.

Thus, in the period between 2008 and 2012, in Stavropol territory 1330 cases of acute poisoning due to toxic effect of alcohol, including 34 cases with lethal outcome (2.5\%) was registered. In 2012 in comparison with 2011 this indicator decreased by 1.2 times (including lethal outcome (1.8 times). It should be noted that in 2012 alcohol poisoning with lethal outcomes amounted to $2.4 \%$.

At the same time the work in accordance with the Concept of state policy to reduce the abuse of alcohol and prevention alcoholism among the population for the period up to 2020 is conducted in Krai. It provides: significant decrease of the level in consumption of alcoholic products; improve efficiency of the system for the prevention of abuse of alcoholic production; increasing the efficiency of the regulation of the alcohol market.

Thus, the analysis of the demographic factors of the environment in the region has allowed drawing the conclusion about the existing social unfavorable environment for the successful migrant integration into the community. In particular, the General health status of the population reflects the complexity of socio-economic and socio-environmental conditions in the region and is characterized by low birth rate, average mortality and sustainable natural population decrease during the last decade. It is of great concern the high rates of alcoholism and drug abuse, especially among young people.

\subsection{Socio-legal Peculiarities of Adaptation of Migrants}

Unfortunately, the legal status of environmental migrants neither international nor Russian legislation is not defined. Only some normative legal acts regulate some aspects of this issue. For example, article 42 of the Constitution guarantees everyone (...the right to compensation of damage caused to his health or property by ecological offence) (Constitution of the Russian Federation, 1993).

Certain provisions of this article have been developed in the Federal law (On security), the Federal law (On protection of population and territories from emergency situations of natural and technogenic character), the Federal law (On radiation safety of population) and other regulatory documents. In the regional legislation there 
are no direct guidance on assistance to migrants who move due to adverse environmental factors, or define their social and legal status.

Only in the Federal law (About forced migrants) in article 2 clearly States that an IDP (...may not be recognized... the person who left the place of residence for economic reasons or because of the famine, epidemics or emergency situations of natural and technogenic character). This circumstance hinders the process of providing legal and social support to the Russian citizen engaged in forced migration for environmental reasons within the country. Indicators of occupational diseases in the territory of Stavropol region registered in the values (in 2008-2012, 0.65-0.8 per 10 thousand employees) below values for several years registered in the Russian Federation (1.5-1.9 per 10 thousand employees respectively) (The Federal Law from 28.12.2010).

The coverage of medical examinations working in harmful working conditions amounted in $201298.6 \%$ against $97.1 \%$ in 2008 .

Overall growth over 5 years (2008-2012) the number of jobs is not meeting sanitary standards EMF decreased 1.8 times

In order to reduce the negative impact of physical factors on the environment and human health, is working on the establishment of sanitary protection zones of industrial objects (The Federal Law from December 21, 1994 ).

A selective analysis of the conditions of legal and social adaptation of migrants in the Stavropol territory, allows to make a conclusion about the existence of a number of sanitary-hygienic standards in the field of health protection of workers in industrial enterprises of the region, which creates favourable conditions of work and, in a sense, some of socio-legal support to new arrivals at the edge of the workers.

\section{Discussion}

The vast analytical material used in the article enabled a complex analysis of socio-ecological situation of Stavropol Krai and distinguishing a number of existing contradictory tendencies that hinder the process of adaptation of migrants to the conditions of the host community.

The results presented in the article enable to conclude that the socio-ecological situation in Stavropol Krai which seems favorable for migrants at first sight is only a possible alternative in comparison with other more disadvantaged in the socio-ecological aspect regions of Russia.

Today, the world has changed, the number of people living on the planet is constantly growing, and global problems caused by this process demonstrate the close relationship of states and at the same time reveal the contradictions between them. This is primarily due to the fact that the very development of human society has always been controversial and accompanied not only by the establishment of harmonious connection with nature, but also by the destruction of the latter. History clearly shows us the uneven development of many countries and peoples, which inevitably leads to the prosperity of some nations and the impoverishment of others. Therefore, some countries have achieved a higher standard of living than others. Such a situation, hunger and poverty caused people of these countries to seek a better life. Hence, a relevant and timeless problem is the study of the issues of social crisis, and the related problems of forced migration, which sometimes has a devastating effect on the already established infrastructure of social communities. All these problems need to be solved.

Therefore, a further study of eco-physiological characteristics of habitat is required: identification of the dependence of human functions on the conditions of life and activity in different physiographic zones, in different periods of the year, day; medical and demographic characteristics that include food quality, sanitary conditions of work and life, fertility and mortality rates, psychological and emotional environment, genetic factors, cases of spread of socially relevant diseases, etc.

Of particular importance is the study of social and legal possibilities of people to meet the standards and legal norms of the host community as well as the study of the legal framework that protects the rights and interests of the individual in the community and influences the social and legal status.

\section{Conclusions}

Thus, a comprehensive analysis socio-ecological situation in the Stavropol region has allowed to allocate contradictory tendencies impeding the process of adaptation of migrants to the conditions in the host community: the trend of migration of the young population from rural areas to urban largely on socio-economic reasons, ignoring the obvious negative socio-ecological features state of the environment in the region.

The General sanitary situation in the region remains unstable, in spite of the objects of the state sanitary and epidemiological surveillance and control of numerous sanitation. This is determined by high infant mortality, low fertility rate, the average death rate, including by reason of injury and accidents and mortality in the 
population of working age. The latter, in turn, may be an indirect consequence of the growth of mental disorders and socially significant diseases among youth.

Favorable at first glance to stay (socio-ecological aspect) of the region is created for migrants only possible alternative for living compared to other more disadvantaged in this sense regions of Russia, but does not provide real social and legal guarantees.

\section{References}

Constitution of the Russian Federation: Basic law of the Russian Federation. (1993, December 25). Russian Newspaper.

Deryapa, N., \& Ryabinin, I. (1977). Adaptation of the person in polar areas of the Earth (p. 302). Moscow: Medicine.

Dukhina, T. (2014). Social optimism and social pessimism in assessing the social well-being of rural residents. Agricultural Bulletin of Stavropol Region, 222-226.

Efimov, Y. (2006). Political consciousness of forced migrants: From the theoretical analysis to interpretation of the results of sociological research. Collection of scientific articles "Political Migratiology", (1), 25-41.

Evtushenko, V. (2010). Ecological migration: Concept, types, place of national legal system. Migratory Right, (2), 13-17.

Gabdrakhmanova, G. (2003). Sociocultural adaptation of refugees and forced migrants in the Republic of Tatarstan (p. 148). Kazan: Institute of History, Academy of Sciences of the Republic of Tatarstan.

Galich, Y. (2006). Migration as a component of the geopolitical process of a mezoregion. Collection of scientific articles "Political Migratiology", (1), 13-18.

Gapich, A. (2006). Dedifferentiation of social roles of a migrant in the conditions of forced migration. Collection of scientific articles "Political Migratiology", (2), 19-41.

Gritsenko, G., Kosov, G., Maslova, T., \& Shulga, M. (2006). Dynamics of integration of forced migrants in the local community: Approach to a sociological community. Collection of Scientific Articles "Political Migratiology", 1, 19-24.

Gudwin-Gill, G. (1997). In M. Levina (Ed.), Status of refugee in International Law (p. 647). YuNITI.

Kobozeva, N. (2006). Labour migration as a social phenomenon in terms of innovative conditions. Collection of scientific articles "Political Migratiology", (1), 41-49.

Olejnikov, Yu. (2001). Ecological conditionality of philosophical transformations. Philosophy of environmental education (p. 346).

Psychologists on migrants and migration in Russia. (2001). Information and Analysis Bulletin, 128-128.

Ryabtsev, A. (2006). Geopolitical vector of migration situation in Russia on the example of Astrakhan Region. Collection of scientific articles "Political Migratiology", (1), 88-100.

Soldatova, G. (2001). Psychology of refugees and forced migrants. Moscow: SMYSL.

The analytical report of the Ministry of Natural Resources and Environmental Protection of Stavropol Krai "About environmental state and environmental management in Stavropol Krai in 2008". (2008).

The Federal Law from 28.12.2010 No. 390-FL "About safety". Retrieved November 19, 2014, from http://www.consultant.ru/law/hotdocs/

The Federal Law from December 21, 1994 No. 68-FL "About protection of population and territories against emergency situations of natural and technogenic character" (with changes and additions). (1994). Retrieved November 19, 2014, from http://base.garant.ru /10107960/

The Federal Law from February 19, 1993 No. 4530-I "About displaced persons" (with changes and additions). Retrieved November 19, 2014, from http://base.garant.ru/10105693/

The Federal Law from January 9, 1996 No. 3-FZ "About radiation safety of population" (with changes and additions). Retrieved November 19, 2014, from //http://base.garant.ru/10108778

The State report of Department of "Rospotrebnadzor" in Stavropol Krai "About conditions of sanitary and epidemiologic wellbeing of people in the Russian Federation" in Stavropol Krai in 2012”. (2012).

\section{Copyrights}

Copyright for this article is retained by the author(s), with first publication rights granted to the journal.

This is an open-access article distributed under the terms and conditions of the Creative Commons Attribution license (http://creativecommons.org/licenses/by/3.0/). 